\title{
On a Probability Distribution in Supply Chain Management
}

\author{
Mohammad Asifur Rahman ${ }^{1, ~ *, ~ A t i k a ~ F a r z a n a ~ U r m i ~}$ \\ ${ }^{1}$ Department of Information Technology, University of the Cumberlands, Williamsburg, Kentucky, USA \\ ${ }^{2}$ Department of Biostatistics, Virginia Commonwealth University, Richmond, Virginia, USA
}

\section{Email address:}

asifur91@gmail.com (M. A. Rahman), farzanaurmi90@gmail.com (A. F. Urmi)

*Corresponding author

\section{To cite this article:}

Mohammad Asifur Rahman, Atika Farzana Urmi. On a Probability Distribution in Supply Chain Management. International Journal of Business and Economics Research. Vol. 9, No. 5, 2020, pp. 348-353. doi: 10.11648/j.ijber.20200905.18

Received: August 19, 2020; Accepted: September 1, 2020; Published: October 20, 2020

\begin{abstract}
The objective of the study was to propose a suitable probability model for supply chain management. As satisfactory service to the customers by different organization is a subject matter of supply chain management, attempt was made to observe the level of satisfaction of the customers visited the banks and mobile operators. Accordingly, data were collected from 560 customers throughout the banking hours in a day of different banks working in Bangladesh. The main questions to the customers were related to the satisfaction of the service rendered by the bank service providers and how much time the customers had to wait to get the service. A contagious probability distribution was fitted assuming the distribution of waiting time as exponential distribution with the assumption of number of customers waiting to follow the Poisson distribution. The percentage of satisfied customers with the service of the bank was 70.7. Satisfaction was noted in 55.1\% visited customers of different mobile operator's office. Level of satisfaction was significantly in declining trend with the increase in ages of the customers. This was true for both the service providing centers. Service satisfaction was in declining rate with the increase in waiting time. The sample data did not provide a suitable probability model according to the assumption.
\end{abstract}

Keywords: Logistic Process, Outsourcing Organization, Service Satisfaction, Waiting Time

\section{Introduction}

Intensive competition in the market place forces the service providers to respond more quickly to customers' needs through faster and quicker service delivery. Increasing customer's awareness and preferences lead to an unprecedented explosion in product variety and management of efficient services. Customers give credit to those service providers who can serve the needs of the customers with excellent quality service, and on time. This problem, specially, arises in business and economies in the name of supply chain management. [1-3].

To be effective in matching demand and supply, the service providers need to collaborate in the supply chain. The chain is influenced by four main factors [4]. These are 1) strategic orientation of the outsourcing organization, 2) perception of service providers, 3 ) customer-service provider relationship, and 4) extent to which the logistics process is outsourced. Customer-service provider relationship is to be developed in such a way that satisfactory service can be provided to achieve a good financial performance of service providers [5]. The performance depends on regulatory body [4] that formulates regulations to meet societal and economical concerns so that it facilitates growth of business and economy [5].

The performance of service providers depends on logistics which encompasses a complex set of activities [6,7]. The complex set of activities require collection of metrics to ideally measure performance and the activities should be maintained as a system so that the decision makers can observe the picture of the logistic process. This is needed to know more about the strategic aspects of supply chain management [8]. Supply chain practitioners need to obtain valuable lesson [9] from the mistakes associated with business process re-engineering implementation. It will help in doing performance analysis through cost, stock-out and lead-time reductions [10-12]. One of the main tasks of supply chain management is to do advance analysis enabling 
informed technology advancements and feature advancements [11].

As one of the components of supply chain management is the study of customer-service provider relationship, we can investigate the satisfaction of customers who are served in different service providing agencies, such as banks, post offices, mobile operators' office, centers for medical services etc., where service is available after waiting in queue. During waiting time the customers may be dissatisfied and even during service they may be dissatisfied. In this paper, attempt was made to fit a probability model to study the distributional pattern of waiting time when there were some dissatisfied customers of different service providers.

\section{Methodology}

For the study the data were collected from 560 respondents who were customers of 5 different banks. From each bank 110 customers were interviewed. Among them 500 were account holders and 60 were found as customers but not the account holders during the data collection. Data were collected by some graduating students of the university under the supervision of the first author through a pre-designed and pre-tested questionnaire during the period of February and March 2019.

The main questions to the customers were related to the satisfaction of the service rendered by the bank service providers and how much time the customers had to wait to get the service. Data were recorded throughout the banking hours in a day.

From the same group of respondents data were also recorded regarding their visit, waiting time and service satisfaction in mobile operators' office. Except waiting time the variables recorded from the respondents were mostly qualitative and these variables were recorded in nominal scale for analytical purpose. Another quantitative variable was the age of the respondents.

As a part of main analysis, a contagious probability distribution was fitted assuming the distribution of waiting time as exponential distribution when customers waited in queue to get the service. The number of waiting customers was assumed to follow the Poisson distribution as the customers were in cluster in a queue. The details of the probability distribution were shown below:

The term contagious distribution was apparently first used by Neyman [13] for a discrete distribution that exhibits clustering or contagious effect. The classical Neyman A type distribution is one well known example of a contagious distribution. However, contagious distributions are used, nowadays, to describe a plethora of distributions, many of which possess complicated probability distribution expressed in terms of special function [14]. Neyman wanted to model the distribution of larvae on a plot of a filed. He assumed that the number of clusters of eggs per unit area, N, follows a Poisson distribution with mean $\theta$, while the number of larvae developing from the eggs in clusters is distributed another Poisson distribution. Gupta et al, Ong, Karh's and Bhuyan discussed such contagious distributions [15-17].

\section{Probability distribution}

A probability distribution to describe the variation in the number of dissatisfied customers' visiting a service point where they wait in queue. This is done by fitting an appropriate model for the distribution of the dissatisfied customers on the basis of the following assumptions:

i. Customers' wait in the queue for some time. It is assumed that the waiting time follows exponential distribution, where mean waiting time varies from period to period in a day. Let the mean time be $\beta$ unit.

ii. On the basis of the mean waiting time the level of satisfaction and dissatisfaction also varies. It is assumed that the number of dissatisfied customers follow Poisson distribution, with mean number of customers $\lambda$. This $\lambda$ varies with the variation of $\beta$.

Let $X$ be the waiting time of the customers in a bank to get a service from the bank. The probability distribution of $X$ is given by

$$
\mathrm{f}(\mathrm{x})=\frac{1}{\beta} e^{-\frac{x}{\beta}} \mathrm{E}(\mathrm{X})=\beta, \mathrm{V}(\mathrm{x})=\beta^{2}
$$

Again, if $\beta$ be the number of customers who are dissatisfied with the service of the customers, the distribution of $\beta$ will be Poisson, where the probability function of $\beta$ is given by

$\mathrm{P}(\beta)=\frac{e^{-\lambda} \lambda^{\beta}}{\beta !}, \quad \lambda>0, \beta=0,1,2, \ldots \ldots \ldots$, where $\mathrm{E}(\beta)=\mathrm{V}(\beta)=\lambda$

If $\mathrm{X}$ is the Gamma distribution, its probability density function is given by

$$
f(x)=\frac{1}{\Gamma \alpha \beta^{\alpha}} e^{-x / \beta} x^{\alpha-1}, x>0, \alpha \text { and } \beta \text { are positive parameters }
$$

If $\alpha=1$, the distribution transforms to exponential one with mean $\beta$

The conditional distribution of Poisson variable under the condition of Gamma distribution is given by

$$
\begin{aligned}
& P(x)=\frac{1}{\Gamma \alpha \beta^{\alpha} x !} \int_{0}^{\infty} e^{\lambda} e^{-\lambda \backslash \beta} \lambda^{x+\alpha-1} d \lambda=\left(\begin{array}{c}
\alpha+x-1 \\
\alpha-1
\end{array}\right)\left(\frac{\beta}{1+\beta}\right)^{x}\left(\frac{1}{1+\beta}\right)^{x} \\
& \text { If } \alpha=1, \quad P(x)=\left(\frac{\beta}{1+\beta}\right)^{x}\left(\frac{1}{1+\beta}\right)=p q^{x}, \text { where } p=\frac{1}{1+\beta}, q=1-p=\frac{\beta}{1+\beta}
\end{aligned}
$$

Here $\mathrm{X}$ is the geometric distribution. Its different characteristics can be obtained from its moment generating function which is $\mathrm{M}_{\mathrm{x}}(\mathrm{t})=\mathrm{p}\left(1-\mathrm{qe}^{\mathrm{t}}\right)^{-1} . \mathrm{E}(\mathrm{X})=\frac{q}{p}$ and $\mathrm{V}(\mathrm{x})=$ $\frac{q}{p^{2}} \quad \beta_{2}=\frac{p^{2}}{q}+9, \beta_{1}=\frac{(1+q)^{2}}{q}$

According to the theory the number of dissatisfied customers among the investigated customers may follow geometric distribution with mean $=\beta$ and variance $=\beta(1+\beta)$.

Besides this distributional characteristic, association 
between service satisfaction and waiting time was also studied.

\section{Result}

The analysis presented here was based on data collected from 560 customers who had visited different public and private banks in a day and were in queue to get a service in the bank. Out of these customers, $79.8 \%$ were the permanent customers of the bank and $77.6 \%$ of them were satisfied with the service of the banks. The overall satisfied customers were $70.7 \%$ in the sample. It indicated that service satisfaction was significantly dependent on customers type $\left[\chi^{2}=53.168, p\right.$ value $=0.000$; Table 1]. Customers who had account in the bank they were more satisfied with the service. Some $(21.6 \%)$ were not regularly satisfied with the service. The proportions of customers of different levels of satisfaction were significantly different $\left[\chi^{2}=368.26, p\right.$ value $\left.=0.000\right]$; Table 1]. Again, service satisfaction was significantly associated with the profession of the customers $\left[\chi^{2}=25.077\right.$, $\mathrm{p}$ value $=0.002$, Table 2]. Among the customers $55.2 \%$ were service persons and business persons and $73.8 \%$ of them were satisfied with the service against the overall $70.7 \%$ satisfied customers in the sample. Only $4.1 \%$ customers were farmers and rate of satisfaction was lowest among them. This study indicated that bank was dedicated to provide satisfactory service to people of white collar job.

Table 1. Distribution of different type of customers according to service satisfaction in the bank.

\begin{tabular}{|c|c|c|c|c|c|c|c|c|}
\hline \multirow{3}{*}{ Account holder } & \multicolumn{6}{|c|}{ Satisfaction of service in bank } & \multicolumn{2}{|c|}{ Total } \\
\hline & \multicolumn{2}{|c|}{ Yes } & \multicolumn{2}{|l|}{ No } & \multicolumn{2}{|c|}{ Not always } & \multirow[b]{2}{*}{$\mathbf{n}$} & \multirow{2}{*}{$\%$} \\
\hline & n & $\%$ & $\mathbf{n}$ & $\%$ & n & $\%$ & & \\
\hline Yes & 347 & 77.6 & 23 & 5.1 & 77 & 17.2 & 447 & 79.8 \\
\hline No & 49 & 43.4 & 20 & 17.7 & 44 & 38.9 & 113 & 20.2 \\
\hline Total & 396 & 70.7 & 43 & 7.7 & 121 & 21.6 & 560 & 100.0 \\
\hline
\end{tabular}

Table 2. Distribution of customers according to their profession and service satisfaction in the bank.

\begin{tabular}{|c|c|c|c|c|c|c|c|c|}
\hline \multirow{3}{*}{ Profession of customer } & \multicolumn{6}{|c|}{ Satisfaction of service in bank } & \multicolumn{2}{|c|}{ Total } \\
\hline & \multicolumn{2}{|c|}{ Yes } & \multicolumn{2}{|l|}{ No } & \multicolumn{2}{|c|}{ Not always } & \multirow{2}{*}{$\mathbf{n}$} & \multirow{2}{*}{$\%$} \\
\hline & $\mathbf{n}$ & $\%$ & $\mathbf{n}$ & $\%$ & n & $\%$ & & \\
\hline Business & 81 & 68.1 & 10 & 8.4 & 28 & 23.5 & 119 & 21.3 \\
\hline Service & 147 & 77.4 & 13 & 6.8 & 30 & 15.8 & 190 & 33.9 \\
\hline Student & 52 & 58.4 & 6 & 6.7 & 31 & 34.8 & 89 & 15.9 \\
\hline Farming & 10 & 43.5 & 3 & 13.0 & 10 & 43.5 & 23 & 4.1 \\
\hline Others & 106 & 76.3 & 11 & 7.9 & 22 & 15.8 & 139 & 24.8 \\
\hline
\end{tabular}

Majority $(75.2 \%)$ of the customers were of middle aged ( 25 - 50 years) and $75.4 \%$ of them were satisfied with the service of the bank. Average age of the customers was 35.71 years with standard deviation, $\sigma=10.44$ years. A very big group $(65.4 \%)$ of younger $(14.5 \%$; age $<25$ years) customers were satisfied with the service [Table 3]. Elderly people (age
50 years and above) were smaller in percentage (10.4\%) but a big amount $(43.1 \%)$ of them were not completely satisfied with the service. However, service satisfaction was significantly associated with age showing an almost declining trend of satisfaction with the increase in age $\left[\chi^{2}=\right.$ 23.310, $\mathrm{p}$ value $=0.003$ ].

Table 3. Distribution of customers according to their age and service satisfaction in the bank.

\begin{tabular}{|c|c|c|c|c|c|c|c|c|}
\hline \multirow{3}{*}{$\begin{array}{l}\text { Age of customer } \\
\text { (in years) }\end{array}$} & \multicolumn{6}{|c|}{ Satisfaction of service in bank } & \multicolumn{2}{|c|}{ Total } \\
\hline & \multicolumn{2}{|c|}{ Yes } & \multicolumn{2}{|l|}{ No } & \multicolumn{2}{|c|}{ Not always } & \multirow{2}{*}{$\mathbf{n}$} & \multirow{2}{*}{$\%$} \\
\hline & n & $\%$ & n & $\%$ & n & $\%$ & & \\
\hline$<25$ & 53 & 65.4 & 6 & 7.4 & 22 & 27.2 & 81 & 14.5 \\
\hline $25-40$ & 239 & 76.6 & 16 & 5.1 & 57 & 18.3 & 312 & 55.7 \\
\hline $40-50$ & 71 & 65.1 & 10 & 9.2 & 28 & 25.7 & 109 & 19.5 \\
\hline $50-60$ & 25 & 56.8 & 7 & 15.9 & 12 & 27.3 & 44 & 7.9 \\
\hline $60^{+}$ & 8 & 57.1 & 4 & 28.6 & 2 & 14.3 & 14 & 2.5 \\
\hline
\end{tabular}

Table 4. Distribution of customers according to waiting time in queue and satisfaction with service in bank.

\begin{tabular}{|c|c|c|c|c|c|c|c|c|}
\hline \multirow{3}{*}{ Waiting time in minutes } & \multicolumn{6}{|c|}{ Satisfaction of service in bank } & \multicolumn{2}{|c|}{ Total } \\
\hline & \multicolumn{2}{|c|}{ Yes } & \multicolumn{2}{|l|}{ No } & \multicolumn{2}{|c|}{ Not always } & \multirow[b]{2}{*}{$\mathbf{n}$} & \multirow{2}{*}{$\%$} \\
\hline & n & $\%$ & $\mathbf{n}$ & $\%$ & n & $\%$ & & \\
\hline$<10$ & 124 & 76.1 & 11 & 6.7 & 28 & 17.2 & 163 & 29.1 \\
\hline $10-20$ & 160 & 73.7 & 11 & 5.1 & 46 & 21.2 & 217 & 38.8 \\
\hline $20-30$ & 78 & 66.1 & 11 & 9.3 & 29 & 24.6 & 118 & 21.1 \\
\hline $30^{+}$ & 34 & 54.8 & 10 & 16.1 & 18 & 29.0 & 62 & 11.1 \\
\hline Total & 396 & 70.7 & 43 & 7.7 & 121 & 21.6 & 560 & 100.0 \\
\hline
\end{tabular}


Majority (38.8\%) of the customers waited in queue for 10 20 minutes and $73.7 \%$ of them were satisfied with the service of the bank as against the overall satisfied customers of $70.7 \%$ in the sample [Table 4]. Only 7.7\% customers were not satisfied and another $21.6 \%$ were not always satisfied with the service of the bank. The average waiting time for the service was $\beta=16.41$ minutes with standard deviation 9.56 minutes. More customers (76.1\%) who had waited for less than 10 minutes were satisfied with the service. Service satisfaction was significantly associated with the waiting time for service as was observed by Chi- square test $\left[\chi^{2}=16\right.$. $864, \mathrm{p}-$ value $=0.05$.]

Now, according to the theory discussed above the conditional distribution of the number of dissatisfied customers under waiting time follows geometric distribution $\mathrm{P}(\mathrm{x})=\mathrm{p} \mathrm{q}^{\mathrm{x}}$, where $\mathrm{p}=0.06$ and $\mathrm{q}=0.94$. But for this distribution of dissatisfied customers the above fitted distribution was not suitable as $\chi^{2}=57.26$, $\mathrm{p}$ value $=0.00$.

Among the investigated customers $56.2 \%$ never visited the mobile phone operator's office or there was no need to visit. Only $43.8 \%$ visited the office and $55.1 \%$ of them were satisfied with the service of the office, $33.5 \%$ were not satisfied always. Another $11.4 \%$ were never satisfied with the service. This differences in the percentages of satisfied customers were significantly different $\left[\chi^{2}=175.13\right.$, $\mathrm{p}$ value $=$ 0.000 Table 5].

Table 5. Distribution of customers visited mobile operator's office and satisfied with the service of the official staffs.

\begin{tabular}{|c|c|c|c|c|c|c|c|c|}
\hline \multirow{3}{*}{$\begin{array}{l}\text { Visited mobile operator's } \\
\text { office }\end{array}$} & \multicolumn{6}{|c|}{ Service satisfaction in office } & \multicolumn{2}{|c|}{ Total } \\
\hline & \multicolumn{2}{|c|}{ Yes } & \multicolumn{2}{|l|}{ No } & \multicolumn{2}{|c|}{ Not always } & \multirow{2}{*}{$\mathbf{n}$} & \multirow{2}{*}{$\%$} \\
\hline & $\mathbf{n}$ & $\%$ & $\mathbf{n}$ & $\%$ & $\mathbf{n}$ & $\%$ & & \\
\hline Yes & 135 & 55.1 & 28 & 11.4 & 82 & 33.5 & 245 & 43.8 \\
\hline No & & & & & & & 315 & 56.2 \\
\hline
\end{tabular}

The visited customers were of different ages. Younger customers (age $<25$ years) were only $18.4 \%$ and $64.4 \%$ of them were satisfied with the service. Elder (age $\geq 50$ years) customers were only $4.1 \%$ and $40 \%$ of them were satisfied. The rate of satisfaction was in decreasing trend with the increase in ages. But, service satisfaction was not statistically associated with the age of the customers $\left[\chi^{2}=7.84\right.$, p-value $=$ 0.100 ; Table 6]. The average age of the visiting customer was 31.96 years with standard deviation 11.26 years.

Table 6. Distribution of mobile operator's office visiting customers according to age and service satisfaction.

\begin{tabular}{|c|c|c|c|c|c|c|c|c|}
\hline \multirow{3}{*}{$\begin{array}{l}\text { Age of customers (in } \\
\text { years) }\end{array}$} & \multicolumn{6}{|c|}{ Service satisfaction in mobile operator's office } & \multicolumn{2}{|c|}{ Total } \\
\hline & \multicolumn{2}{|c|}{ Yes } & \multicolumn{2}{|c|}{ No } & \multicolumn{2}{|c|}{ Not always } & \multirow{2}{*}{$\mathbf{n}$} & \multirow{2}{*}{$\%$} \\
\hline & $\mathbf{n}$ & $\%$ & $\mathbf{n}$ & $\%$ & n & $\%$ & & \\
\hline$<25$ & 29 & 64.4 & 6 & 6.1 & 10 & 15.1 & 45 & 18.4 \\
\hline $40-50$ & 16 & 39.0 & 6 & 14.6 & 19 & 46.3 & 41 & 16.7 \\
\hline $50-60$ & 3 & 42.9 & 1 & 14.2 & 3 & 42.9 & 7 & 2.9 \\
\hline $60^{+}$ & 1 & 33.3 & 2 & 66.7 & 0 & 0.0 & 3 & 1.2 \\
\hline
\end{tabular}

The visiting customers in mobile operators' office were of different professions. Majority (60.4\%) of them were service persons and business persons and $57.4 \%$ of them were satisfied with the service rendered by the official staffs. There were only $2.4 \%$ farmers but $67.7 \%$ of them were satisfied.
Out of $22.0 \%$ visiting students $50 \%$ were satisfied with the service. Least satisfaction was noted among students. However, service satisfaction was not associated with profession of the visiting customers $\left[\chi^{2}=7.45, \mathrm{p}\right.$-value $>0.05$ Table 7].

Table 7. Distribution of mobile operator's office visiting customers according to their profession and service satisfaction.

\begin{tabular}{|c|c|c|c|c|c|c|c|c|}
\hline \multirow{3}{*}{$\begin{array}{l}\text { Profession of visiting } \\
\text { customers }\end{array}$} & \multicolumn{6}{|c|}{ Service satisfaction in mobile operator's office } & \multicolumn{2}{|c|}{ Total } \\
\hline & \multicolumn{2}{|c|}{ Yes } & \multicolumn{2}{|c|}{ No } & \multicolumn{2}{|c|}{ Not always } & \multirow{2}{*}{$\mathbf{n}$} & \multirow{2}{*}{$\%$} \\
\hline & $\mathbf{n}$ & $\%$ & $\mathbf{n}$ & $\%$ & $\mathbf{n}$ & $\%$ & & \\
\hline Service & 46 & 54.1 & 10 & 11.8 & 29 & 34.1 & 85 & 34.7 \\
\hline Business & 39 & 61.9 & 10 & 15.9 & 14 & 22.2 & 63 & 25.7 \\
\hline Student & 27 & 50.0 & 6 & 11.1 & 21 & 38.9 & 54 & 22.0 \\
\hline Farming & 4 & 67.2 & 0 & 0.0 & 2 & 33.3 & 6 & 2.4 \\
\hline Total & 135 & 55.1 & 28 & 11.4 & 82 & 33.5 & 245 & 100.0 \\
\hline
\end{tabular}

The average waiting time in mobile operator's office was 15.96 minutes with standard deviation 9.03 minutes [Table 8]. Majority (44.5\%) of the visiting customers had to wait for $10-20$ minutes and $54.1 \%$ of them were satisfied with the provided service. The next bigger group of customers $(27.3 \%)$ had to wait less than 10 minutes and higher proportion $(61.2 \%)$ of them were satisfied with the service. Rate of satisfaction was in declining trend with the increasing 
trend of waiting time. However, level of satisfaction was not

$0.05]$. statistically associated with waiting time $\left[\chi^{2}=2.98, \mathrm{p}\right.$ value $>$

Table 8. Distribution of mobile operator's office visiting customers according to their waiting time and service satisfaction.

\begin{tabular}{|c|c|c|c|c|c|c|c|c|}
\hline \multirow{3}{*}{$\begin{array}{l}\text { Waiting time of visiting } \\
\text { customers (in minutes) }\end{array}$} & \multicolumn{6}{|c|}{ Service satisfaction in mobile operator's office } & \multicolumn{2}{|c|}{ Total } \\
\hline & \multicolumn{2}{|c|}{ Yes } & \multicolumn{2}{|c|}{ No } & \multicolumn{2}{|c|}{ Not always } & \multirow{2}{*}{$\mathbf{n}$} & \multirow{2}{*}{$\%$} \\
\hline & $\mathbf{N}$ & $\%$ & n & $\%$ & $\mathbf{n}$ & $\%$ & & \\
\hline$<10$ & 41 & 61.2 & 8 & 11.9 & 18 & 26.9 & 67 & 27.3 \\
\hline $10-20$ & 59 & 54.1 & 10 & 9.2 & 40 & 36.7 & 109 & 44.5 \\
\hline $20-30$ & 24 & 51.1 & 3 & 6.4 & 20 & 42.6 & 47 & 19.2 \\
\hline $30^{+}$ & 11 & 50.0 & 7 & 31.8 & 4 & 18.2 & 22 & 9.0 \\
\hline Total & 135 & 55.1 & 28 & 11.4 & 82 & 33.5 & 245 & 100.0 \\
\hline
\end{tabular}

The conditional distribution of number of dissatisfied customers under waiting distribution is $P(x)=p q^{x}$, where for the dissatisfied customers of the mobile operators' office $\mathrm{p}=0.059$ and $\mathrm{q}=0.941$ as the average waiting time was $\beta=$ 15.96 minutes. This distribution was not fitted well as $\chi^{2}=$ 144.14 with $\mathrm{p}$-value $=0.000$.

\section{Discussion and Conclusion}

Supply chain management is a problem in business and economics. The problem arises due to the competition in the market in serving the customers efficiently and hurriedly. Customers dissatisfaction may lead the organization towards bankrupts. So, industrialists, business persons, and suppliers take efficient steps in serving the customers properly and timely.

Keeping this view in mind an attempt was made to observe the service satisfaction of some customers of some of the operating bank in Bangladesh and some of the mobile operators. The number of investigated customers was 560 and $70.7 \%$ of them were satisfied with the service of the bank. But service satisfaction was in declining trend with the increase in age of the customers. Business persons and service persons were more satisfied with service compared to the satisfaction of other professionals. The average waiting time in the bank was 16.41 minutes and. But satisfaction of the customers was in declining trend with the increase in waiting time. However, the distribution for the dissatisfied customers was not well fitted.

The investigated customers were also questioned regarding their visit to the mobile operator's office and regarding their satisfaction with the service rendered by the staff members of the office. Only $43.8 \%$ of the same group of customers visited the office and $55.1 \%$ of them were satisfied with the service. Rate of satisfaction was significantly declining with the increase in age. The average age of the visited customers was 31.96 years. In this case also, more service persons and business persons were satisfied, though there was no significant association between service satisfaction and profession of customers. Satisfaction was also not associated with the waiting time to get a service. The average waiting time was 15.96 minutes. The proposed probability model for the dissatisfied customers was not fitted well.

The service to the customers in both bank and mobile operator's office was satisfactory. There was scope to provide more satisfactory service to the elderly people and to the people not involved in white collar job.

\section{Acknowledgements}

We sincerely thank Professor K. C. Bhuyan, former Professor of Statistics and Business Statistics, American International University-Bangladesh. Who had encouraged us to do this research work. We have completed the work under his supervision.

\section{References}

[1] Togar M. Simatupang, R. Sridhaan (2002): The collaborate supply chain. The International Journal of Logistics $\begin{array}{llll}\text { Management, } & 10 & \text { (2), } & 41-55 \text {; }\end{array}$ https://doi.org/10.1108/09574099910805987.

[2] Peter Finch (2004): $\beta$ Supply chain risk management, supply chain management, An International Journal, 9 (2), 183-196; https://doi.org/10.1108/13598540410527079.

[3] Samir K. Srivastava (2007): Green supply chain management: A state of the art review. British Academy Management; https://doi.org./10.1111/J.1468-2370.00202.X.

[4] Yemisi A. Bolumote (2001): The supply chain role of third party logistics providers, The International Journal of $\begin{array}{llll}\text { Logistics } & \text { Management, } 12 & \text { (2), 87-1402; }\end{array}$ https://doi.org/10.1108/09574090110806316.

[5] Rachel Duffy, Andrew Fearne 92004): The impact of supply chain partnership on supplier performance, The International Journal of Logistics Management, 15 (1), 57-72; https://doi.org./10.1108/09574090410700239

[6] Chris Caplia, Yosssi Shefli (1995): A review and evaluation of logistic performance systems, The International Journal of Logistics Management, 6 (1), 61-74; https://doi.org/10.110809574099510805279

[7] Lisa M. Ellram, Marth C. Cooper (1990): Supply chain management, partnership, and the shipper-third party relationship. The International Journal of Logistics $\begin{array}{llll}\text { Management, } & 1 & \text { (2), } & 1-10 \text {; }\end{array}$ https://doi.org/10.1108/95740939080001276

[8] Christian Bechtel, Jayarth Jayaram (1997): Supply chain management: A strategic perspective. The International Journal of Logistics Management, 8 (1), 15-34; https://doi.org/10.1108/09574099710805565 
[9] Rachel Rurgess (1998): Avoiding supply chain management failure: Lessons from business process re-engineering, The International Journal of Logistics Management, 9 (1), 15-22, https://doi.org/10.1108/0957409981080571

[10] Cristina Gimenez (2003): Supply chain management as a competitive advantage in the Spanish grocery sector, The International Journal of Logistics Management, 14 (1), 77-78, https://doi.org/10.1108/109574090310806558

[11] Tage Skjoett-Larsen (1991): Supply chain management: A new challenge for researchers and managers in the logistics, The International Journal of Logistics Management, 10 (2), 41-55, https://doi.org/10.1108/09574099910805987

[12] Larry C. Giunipero, Richard R. Brand (1996): Purchasing role in supply chain management, The International Journal of Logistics Management, 7 (1), 29-38, https://doi.org/10.1108/09574099610805412
[13] Neyman. J. (1939): On a new class of contagious distributions applicable in entomology and bacteriology, Ann. Math. Statist, $10(1), 35-57$

[14] Johnson, N. L; Kemp, A. W. and Kotz, S. (2005): Univariate discrete distributions, John Wiley and Sons. Inc. New York.

[15] Gupta, R. C. and Ong, S. H (2005): Analysis of long tail count data by Poisson mixtures, Comm. Stat, 34 (3), 557-574.

[16] Karlis, D, Xekalaki, E (2005): Mixed Poisson distributions, Int. Stat. Rev, 73, 35-58.

[17] Bhuyan, K. C. (2003): On a probability model for pulmonate slugs (Mollosca: Gastropoda: Palmonata) of north. eastern. Libya, AJSE. 